\title{
PERCUTANEOUS NEEDLE ASPIRATION: A PROSPECTIVE STUDY OF 100 CASES
}

\author{
Malvika Sawai', Bhuvan², Rakesh K. Gupta3 ${ }^{3}$ Kedar S. Shahi \\ ${ }^{1} 3^{\text {rd }}$ Year Junior Resident, Department of Surgery, Government Medical College, Haldwani Nainital, Uttarakhand. \\ ${ }^{2}$ Associate Professor, Department of Surgery, Government Medical College, Haldwani Nainital, Uttarakhand. \\ ${ }^{3}$ Senior Resident, Department of Surgery, Government Medical College, Haldwani Nainital, Uttarakhand. \\ ${ }^{4}$ Professor, Department of Surgery, Government Medical College, Haldwani Nainital, Uttarakhand.
}

\section{ABSTRACT}

Breast abscess is defined as an acute soft tissue infection which is characterized by localized pain, swelling and redness associated with a mass that may or may not be fluctuant.[1,2] Most breast abscesses develop as a complication of lactational mastitis.

\section{OBJECTIVES OF STUDY}

To assess the feasibility and effectiveness of percutaneous needle aspiration of breast abscesses as a day care procedure.

\section{METHOD AND METHODOLOGY}

This prospective study was conducted in patients with breast abscess attending the surgical OPD of a tertiary centre. A total of 100 patients with breast abscess giving consent to participate in study were included in the study. Percutaneous needle aspiration of pus under local anaesthesia was done with 18/16G needle. Empirical antibiotic therapy with amoxicillin+clavulanic acid was started. Aspirated pus was sent for bacteriological study. The antibiotics were changed in accordance to sensitivity report if needed.

\section{RESULTS}

The mean age of the patients was 28.11 years and youngest patient was of 17 years married female. Most of the patients were lactating female in age group of 25-30 years followed by age group of 20-25 years. Topographically, most breast abscess were located in upper outer quadrant in 38 patients followed by 32 patients having abscess in central region. The mean volume of pus on ultrasonography was $57.32 \mathrm{~mL}$ and mean volume of pus on aspiration was $45.75 \mathrm{~mL}$. The mean number of aspiration was 2.18 . All of the aspirated pus was sent for culture and sensitivity. Among these, 12 samples of pus were sterile and 88 samples showed growth of organism.

\section{CONCLUSION}

With appreciable cure rate by repeated needle aspiration, this method can be preferred as treatment of breast abscess in selected patients.

\section{KEYWORDS}

Breast Abscess, Aspiration, Drainage.

HOW TO CITE THIS ARTICLE: Sawai M, Bhuvan, Gupta RK, et al. Percutaneous needle aspiration: a prospective study of 100 cases. J. Evolution Med. Dent. Sci. 2016;5(44):2767-2770, DOI: 10.14260/jemds/2016/646

\section{INTRODUCTION}

Breast abscess is defined as an acute soft tissue infection which is characterized by localized pain, swelling and redness associated with a mass that may or may not be fluctuant.[1,2] Most breast abscesses develop as a complication of lactational mastitis. The incidence of breast abscess ranges from 0.4 to $11 \%$ of all lactating mothers. ${ }^{[3]}$ Breast abscesses are more common in obese patients and smokers than in the general population..$^{[4]}$ The standard clinical treatment of breast abscess has been incision and drainage of pus and antibiotics. This procedure has its own limitations like pain, fear of incision, prolonged healing time, difficulty in breastfeeding and the possibility of milk fistula and unsatisfactory cosmetic outcome.[5]

Financial or Other, Competing Interest: None.

Submission 13-04-2016, Peer Review 12-05-2016,

Acceptance 17-05-2016, Published 02-06-2016.

Corresponding Author:

Dr. Kedar S. Shahi,

Professor,

Department of Surgery,

Government Medical College,

Haldwani, Nainital,

Uttarakhand.

E-mail: kedar_shahi@rediffmail.com

DOI: $10.14260 /$ jemds/2016/646
Recently, some authors have reported that breast abscesses can also be treated by repeated needle aspirations and suction drainage.[5] The purpose of this article is to evaluate the repeated needle aspirations as a method of breast abscess treatment.

\section{Objectives of Study}

To assess the feasibility and effectiveness of percutaneous needle aspiration of breast abscesses as a day care procedure.

\section{METHOD AND METHODOLOGY}

This prospective study was conducted in patients with breast abscess attending the surgical OPD of a tertiary centre. A total of 100 patients with breast abscess giving consent to participate in study were included in the study. The patients not giving consent, large abscess of $>4 \mathrm{~cm}$, diabetics and having features of septicaemia were excluded from the study. The diagnosis of breast abscess was made on basis of history and clinical examination. All patients underwent a preliminary ultrasonography of bilateral breasts and axillae to assess the size of abscess cavity and nature of the pus. All patients were investigated for complete haemogram, coagulation profile, blood glucose and chest X-ray. Percutaneous needle aspiration of pus under local anaesthesia was done with 18/16G needle.

Empirical antibiotic therapy with amoxicillin+clavulanic acid was started. Aspirated pus was sent for bacteriological 
study. The antibiotics were changed in accordance to sensitivity report if needed. Repeated aspiration on follow-up was done after assessing clinically and/or ultrasonographically. Various parameters regarding clinical and microbiological profile was recorded.

\section{RESULTS}

The study was conducted in total of 100 patients. The mean age of the patients was 28.11 years and youngest patient was of 17 years married female. Most of the patients were lactating female in age group of 25-30 years followed by age group of 20-25 years. In the present study, lactational breast abscess was seen in 89 patients and non-lactational breast abscess in 11 patients. The mean age for lactational breast abscess was 27.47 years, whereas the mean age for non-lactational breast abscess was 33.27 years (Table 1).

\begin{tabular}{|c|c|c|c|}
\hline $\begin{array}{c}\text { Age } \\
\text { Group } \\
\text { (In Years) }\end{array}$ & $\begin{array}{c}\text { Lactational } \\
\text { Breast } \\
\text { Abscess } \\
\text { (n) }\end{array}$ & $\begin{array}{c}\text { Non- } \\
\text { Lactational } \\
\text { Breast } \\
\text { Abscess (n) }\end{array}$ & Total (n) \\
\hline $15-20$ & 2 & 1 & 3 \\
\hline $20-25$ & 26 & 1 & 27 \\
\hline $25-30$ & 45 & 3 & 49 \\
\hline $30-35$ & 12 & 2 & 14 \\
\hline $35-40$ & 3 & 1 & 4 \\
\hline $40-45$ & 0 & 2 & 2 \\
\hline$>45$ & 0 & 1 & 1 \\
\hline $\begin{array}{c}\text { Mean of } \\
\text { Age }\end{array}$ & 27.47 Years & 33.27 Years & $\begin{array}{c}28.11 \\
\text { Years }\end{array}$ \\
\hline $\begin{array}{c}\text { Range of } \\
\text { Age }\end{array}$ & $17-38$ Years & $20-49$ Years & $\begin{array}{c}17-49 \\
\text { Years }\end{array}$ \\
\hline \multicolumn{2}{|c|}{ Table 1: Age Distribution of the Patients } \\
\hline
\end{tabular}

The breast abscess was located nearly equally on both sides; 52 patients had breast abscess on left side, while 48 patients had abscess on right side. Topographically, most breast abscesses were located in upper outer quadrant in 38 patients followed by 32 patients having abscess in central region. Only 2 patients had abscess in lower inner quadrant (Table 2).

\begin{tabular}{|c|c|}
\hline Location & N (\%) \\
\hline Right Breast & $52(52.00 \%)$ \\
\hline Left Breast & $48(48.00 \%)$ \\
\hline Upper Outer & $38(38.00 \%)$ \\
\hline Lower Outer & $16(16.00 \%)$ \\
\hline Upper Inner & $12(12.00 \%)$ \\
\hline Lower Inner & $2(2.00 \%)$ \\
\hline Central & $32(32.00 \%)$ \\
\hline \multicolumn{2}{|c|}{ Table 2: Location of Breast Abscess } \\
\hline
\end{tabular}

The patients presented with classical signs of acute inflammation. These comprised of pain, breast lump, fever, erythema and fluctuation. The 'fluctuation sign' was elicited in $<20 \%$ patients ( $\mathrm{n}=17) ; 21$ patients also had ipsilateral axillary node enlargement. The mean duration of presentation was 4.7 days.

The mean volume of pus on ultrasonography was $\mathbf{5 7 . 3 2}$ $\mathrm{mL}$ and mean volume of pus on aspiration was $45.75 \mathrm{~mL}$. However, most of the patient required multiple aspiration of the abscess, but few patients required only single aspiration of abscess. The mean number of aspiration was 2.18 . The mean volume of pus on first aspiration was $22.42 \mathrm{~mL}$. The mean number of aspiration increased with increasing size of abscess cavity. The patients in whom the aspirated pus was low in first aspiration yielded large volume of pus on second aspiration, possibly due to liquefaction of the pus (Table 3).

\begin{tabular}{|c|c|c|c|c|c|c|}
\hline \multirow[b]{2}{*}{$\begin{array}{l}\text { Abscess Size } \\
\text { on USG (n) }\end{array}$} & \multirow{2}{*}{$\begin{array}{c}\text { Total Mean } \\
\text { Volume of } \\
\text { Abscess } \\
\text { Aspirated }\end{array}$} & \multicolumn{4}{|c|}{ Mean Volume of Pus Aspirated } & \multirow{2}{*}{$\begin{array}{c}\text { Mean No. o } \\
\text { Aspiration } \\
\text { Required }\end{array}$} \\
\hline & & $\begin{array}{c}\text { First } \\
\text { Aspiration }\end{array}$ & $\begin{array}{c}\text { Second } \\
\text { Aspiration }\end{array}$ & $\begin{array}{c}\text { Third } \\
\text { Aspiration }\end{array}$ & $\begin{array}{c}\text { Fourth } \\
\text { Aspiration }\end{array}$ & \\
\hline 20-30 ML (11) & $20.11 \mathrm{ML}$ & 12.7 ML (11) & 16.3 ML (5) & - & - & 1.45 \\
\hline 30-40 ML (15) & $32.68 \mathrm{ML}$ & 19.3 ML (15) & 25.1 ML (8) & - & - & 1.53 \\
\hline 40-50 ML (18) & $41.68 \mathrm{ML}$ & 22.4 ML (18) & 28.8 ML (11) & 15.1 ML (2) & - & 1.72 \\
\hline 50-60 ML (23) & $51.71 \mathrm{ML}$ & $23.1 \mathrm{ML}(23)$ & 27.9 ML (20) & 14.3 ML (7) & - & 2.17 \\
\hline 60-70 ML (17) & $61.28 \mathrm{ML}$ & 26.5 ML (17) & 29.0 ML (17) & 8.7 ML (10) & 5.6 ML (2) & 2.7 \\
\hline 70-80 ML (9) & $69.33 \mathrm{ML}$ & 26.7 ML (9) & 33.4 ML (9) & 10.8 ML (6) & 6.1 ML (3) & 3.0 \\
\hline $80-90$ ML (5) & $78.4 \mathrm{ML}$ & $28.1 \mathrm{ML}(5)$ & 33.9 ML (5) & 13.2 ML (5) & $8.0 \mathrm{ML}(2)$ & 3.4 \\
\hline 90-100 ML (2) & 83.2 ML & 23.9 ML (2) & 38.7 ML (2) & 10.2 ML (2) & 10.4 ML (2) & 4 \\
\hline $57.32 \mathrm{ML}$ & $45.75 \mathrm{ML}$ & 22.42 ML (100) & 28.54 ML (77) & 11.53 ML (32) & 7.38 ML (9) & 2.18 \\
\hline \multicolumn{7}{|c|}{ Table 3: Abscess Size and Volume of Pus Aspirated } \\
\hline
\end{tabular}

The average time needed for healing was 11.9 days. All of the patients were followed up for average period of 2.5 months. There was antibioma formation in 2 patients and one patient required incision and drainage of breast abscess in whom the symptoms failed to subside after four aspiration. None of the patient reported recurrent breast abscess.

All of the aspirated pus was sent for culture and sensitivity. Among these, 12 samples of pus were sterile and 88 samples showed growth of organism. The pus samples of 62 patients showed growth of Staphylococcus aureus followed by E. coli seen in 13 patients. The growth of Bacteroides, Acinetobacter and Salmonella were seen in one patient each. The pus of 7 patients showed growth of two organisms. Out of the 7 patients, 3 patients showed mixed growth of Staphylococcus aureus and E. coli (Table 4).

\begin{tabular}{|c|c|}
\hline Organism & N (\%) \\
\hline Sterile Culture & $12(12.00 \%)$ \\
\hline Staphylococcus Aureus & $59(59.00 \%)$ \\
\hline $\begin{array}{c}\text { Methicillin Resistant } \\
\text { Staphylococcus Aureus }\end{array}$ & $5(5.00 \%)$ \\
\hline E. Coli & $15(15.00 \%)$ \\
\hline Pseudomonas & $5(5.00 \%)$ \\
\hline Klebsiella & $6(6.00 \%)$ \\
\hline
\end{tabular}




\begin{tabular}{|c|c|}
\hline Streptococcus & $2(2.00 \%)$ \\
\hline Bacteroides & $1(1.00 \%)$ \\
\hline Acinetobacter & $1(1.00 \%)$ \\
\hline Salmonella & $1(1.00 \%)$ \\
\hline Mixed Flora & $7(7.00 \%)$ \\
\hline Staphylococcus Aureus+Streptococcus & $1(1.00 \%)$ \\
\hline Staphylococcus Aureus+E. Coli & $3(3.00 \%)$ \\
\hline Pseudomonas+E. Coli & $1(1.00 \%)$ \\
\hline Klebsiella+E. Coli & $1(1.00 \%)$ \\
\hline Streptococcus+Klebsiella & $1(1.00 \%)$ \\
\hline Table 4: Bacteriological Profile of Breast Abscess \\
\hline
\end{tabular}

Staphylococcus aureus were $100 \%$ sensitive to vancomycin and showed considerable susceptibility to coamoxiclav, third generation cephalosporins, amikacin, imipenem and linezolid. MRSA were $100 \%$ sensitive to vancomycin. E. coli, Klebsiella and Pseudomonas showed high level resistance to third generation cephalosporins and fluoroquinolones, but had good sensitivity to amikacin, piperacillin+tazobactam, imipenem, linezolid and vancomycin. Other rare organism also showed good sensitivity to imipenem, linezolid, amikacin and vancomycin (Table 5).

\begin{tabular}{|c|c|c|c|c|c|c|c|c|c|}
\hline Drugs & $\begin{array}{c}\text { Staph } \\
\text { Aureus } \\
(\%)\end{array}$ & $\begin{array}{l}\text { MRSA } \\
\text { (\%) }\end{array}$ & $\begin{array}{c}\text { E. } \\
\text { coli } \\
(\%) \\
\end{array}$ & Klebsiella\% & $\begin{array}{c}\text { Acineto- } \\
\text { bacter } \\
(\%) \\
\end{array}$ & $\begin{array}{c}\text { Pseudo- } \\
\text { monas } \\
(\%)\end{array}$ & $\begin{array}{l}\text { Bacte- } \\
\text { roides } \\
(\%) \\
\end{array}$ & $\begin{array}{c}\text { Strepto- } \\
\text { coccus } \\
(\%) \\
\end{array}$ & $\begin{array}{c}\text { Salmonella } \\
(\%)\end{array}$ \\
\hline Ampicillin & - & - & - & - & - & - & - & - & - \\
\hline Co-amoxiclav & 81.3 & - & - & - & 100 & - & - & 50 & - \\
\hline $\begin{array}{c}\text { Piperacillin + } \\
\text { Tazobactam }\end{array}$ & 85.9 & 40 & 73.3 & 66.6 & 100 & 80 & - & 50 & 100 \\
\hline Ceftriaxone & 78.1 & - & 46.6 & 33.3 & - & 40 & - & - & 100 \\
\hline $\begin{array}{l}\text { Ceftriaxone } \\
+ \text { Sulbactam }\end{array}$ & 82.8 & 40 & 66.6 & 66.6 & 100 & 60 & - & 100 & 100 \\
\hline Amikacin & 78.1 & 40 & 80 & 66.6 & 100 & 100 & - & - & 100 \\
\hline Gentamicin & 70.3 & - & 80 & 33.3 & - & 60 & - & - & 100 \\
\hline Imipenem & 96.9 & 60 & 93.3 & 100 & 100 & 100 & - & - & 100 \\
\hline Cotrimoxazole & 23.4 & - & 40 & 33.3 & - & - & - & 100 & - \\
\hline Ciprofloxacin & 23.4 & - & 66.6 & 33.3 & - & 40 & - & - & 100 \\
\hline Levofloxacin & 25 & - & 66.6 & 33.3 & - & 60 & - & - & 100 \\
\hline Linezolid & 95.3 & 80 & 100 & 83.3 & 100 & 80 & 100 & 100 & 100 \\
\hline Vancomycin & 100 & 100 & - & - & - & - & 100 & 100 & - \\
\hline
\end{tabular}

\section{DISCUSSION}

The lactational breast abscess is being a common type. The risk factors for lactational breast abscess formation include the first pregnancy at maternal age over 30 years, pregnancy more than 41 weeks of gestation and mastitis.[4,5] Non-lactational abscesses can be classified as central, peripheral or skin associated.[6] Patients with non-lactational abscesses, diabetics and smokers are likely to develop recurrent infections. Central (Periareolar) non-lactational abscesses are usually due to periductal mastitis.[7]

The standard treatment of breast abscess is incision and drainage under general/topical anaesthesia. This procedure needs hospital stay and have various drawbacks. In need of a less invasive method and good cosmetic outcome, various methods have been suggested. These methods are repeated needle aspirations.[8,9], ultrasound-guided aspiration of abscess.[10,11], incision and removal of abscess cavity wall.[12], negative suction drainage after incision and primary closure of the abscess cavity.[13] and needle aspirations followed by antibiotics instillation. $[14,15]$

In the present study in 100 patients, the mean age was 28.11 years. Two studies have reported mean age of approximately 32 years. ${ }^{[16-18]}$ The presentation at younger age could be attributed to younger age of marriage and child birth in Uttarakhand. Also most patients had lactational breast abscess in $89 \%$, which is comparable to other study.[16,19]

The mean volume of the pus in the abscess cavity was $57.32 \mathrm{~mL}$ and mean volume of the pus aspirated was $47.75 \mathrm{~mL}$. The volume of aspirated pus was comparable to findings by other author.[20] The literature available mostly have considered the size of the abscess cavity rather than volume.
The mean number of aspiration needed was 2.18 and is comparable to results of Tan et al with mean aspiration of 2.4.[20] However, some study report lower number of aspiration needed.[19] The mean healing time was 11.9 days. Other study reported healing time of around 14 days after repeated needle aspirations. ${ }^{[21]}$

The most common isolated pathogen was Staphylococcus aureus including MRSA in $64 \%$, which is comparable to findings in other study.[16-18,21] The possible reason for this could be that most of the patients had lactational breast abscess. Nonetheless, rare organisms were also isolated in few cases like Bacteroides, Streptococcus, Acinetobacter and Salmonella.

The patients treated by repeated needle aspiration was $97 \%$ and is more than findings in other study.[16,19,22] The complication rate was lower compared to other study.[16] Antibioma formation was seen in 2 patients, which resolved spontaneously on conservative management and only 1 patient needed incision and drainage. The lower complication rate could be because diabetics, septicaemic and abscess $>4 \mathrm{~cm}$ were excluded from the study. In addition to these, the antibiotics were changed as soon the culture and sensitivity reports were available.

The patient satisfaction was excellent, as there were no scar and cosmesis result was good. The apprehensive patients were especially happier towards needle aspirations and avoiding ugly scar marks left after incision and drainage. Other study has also reported better cosmesis.[16,17,19,21,23,24] 


\section{CONCLUSION}

Breast abscess is a common problem, especially in lactating female. The traditional treatment by incision and drainage causes a considerable distress in patients. This also require hospital stay and leaves an ugly scar mark.

With the present treatment option by repeated needle aspirations and antibiotics, the needs of general anaesthesia, hospital stay and scar marks could be avoided. The other complication like pain, regular dressings, problems in breast feeding and mammary duct fistula are also avoided. With appreciable cure rate by repeated needle aspiration, this method can be preferred as treatment of breast abscess in selected patients.

\section{REFERENCES}

1. Scholefield JH, Duncan JL, Rogers K. Review of a hospital experience of breast abscesses. Br J Surg 1987;74(6):46970.

2. Garrison RN, Fry DE. Surgical infection. In: Lawrence PF, editor. Essential of general surgery. Philadelphia: lippincott williams and wilkins 2000;3rd ed:123-39.

3. Dener C, Inan A. Breast abscesses in lactating women. World J Surg 2003;27(2):130-3.

4. Bharat A, Gao F, Aft RL. Predictors of primary breast abscesses and recurrence. World J Surg 2009;33(12):2582-6.

5. Berens PD. Prenatal, intrapartum, and postpartum support of the lactating mother. Paediatr Clin North Am 2001;48(2):365-75.

6. Kataria K, Srivastava A, Dhar A. Management of lactational mastitis and breast abscesses: review of current knowledge and practice. Indian J Surg 2013;75(6):430-5.

7. Rizzo M, Peng L, Frisch A. Breast abscesses in nonlactating women with diabetes: clinical features and outcome. Am J Med Sci 2009;338(2):123-6.

8. Dixon JM. Repeated aspirations of breast abscesses in lactating women. BMJ 1988;297(6662):1517-8.

9. Kaur N. Outpatient treatment of breast abscesses by repeated aspirations. Hospital Today 2001;11:64-78.

10. Garg P, Rathee SK, Lal A. Ultrasonically guided percutaneous drainage of breast abscess. J Indian Med Assoc 1997;95(11):584-5.
11. O'Hara RJ, Dexter SP, Fox JN. Conservative management of infective mastitis and breast abscesses after ultrasonographic assessment. Br J Surg 1996;83(10): 1413-4.

12. Jones NA, Wilson DH. The treatment of breast abscesses by incision, curettage and primary suture under antibiotic cover. Br J Surg 1976;63(6):499-501.

13. Azao OG, Ladipo JK, Al Saigh AA, et al. Primary closure of breast abscesses compared with the conventional gauze packing and daily dressing. West Afr J Med 1994;13(1):28-30.

14. Florey ME, Macvine JS, Bigby MAM. Treatment of breast abscesses with penicillin. BMJ 1946;2(4483):846-8.

15. Kaur N. Treatment of breast abscesses using systemic and local antibiotics. Indian Journal of Surgery 2002; 64(6):502-5.

16. Gojen Singh, Gojendra Singh, Ramesh Singh L, et al. Management of breast abscess by repeated aspiration and antibiotics. JMS 2012;26(3):189-91.

17. Elagili F, Abdullah N, Fong L, et al. Aspiration of breast abscess under ultrasound guidance: outcome obtained and factors affecting success. Asian J Surg 2007;30(1): $40-4$.

18. Ulitzsch D, Nyman MK, Carlson RA. Breast abscess in lactating women: US-guided treatment. Radiology 2004;232(3):904-9.

19. Schwarz RJ, Shrestha R. Needle aspiration of breast abscesses. Am J Surg 2001;182(2):117-9.

20. Tan SM, Low SC. Non-operative treatment of breast abscesses. ANZ J Surg 1998;68(6):423-4.

21. Dixon JM. Outpatient treatment of non lactational breast abscess. BJS 1992;79(1):56-7.

22. Hansen PB, Axelsson CK. Treatment of breast abscess an analysis of patient material and implementation of recommendations. Ugeskr Laeger 2003;165(2):128-31.

23. Eryilmaz R, Sahin M, Hakan Tekelioglu $M$, et al. Management of lactational breast abscesses. Breast 2005;14(5):375-9.

24. Karstrup S, Nolsøe C, Brabrand K, et al. Ultrasonically guided percutaneous drainage of breast abscesses. Acta Radiol 1990;31(2):157-9. 